\title{
Covid-19 Pandemic: Empirical Study of Determinants of Purchase Decision
}

\author{
ANDIKA BASKARA, SUKAMTO \\ Management Study Program of The Faculty of Economics \\ Muhammadiyah University Semarang \\ Kedungmundu Street No.18, Semarang City, Centered of Java 50273 \\ INDONESIA
}

\begin{abstract}
The purpose of this study was to determine the impact of lifestyle and price on purchasing decisions. Individual variables include lifestyle and price. The regulatory variable is the Covid-19 plague, and the dependent variable is the purchase decision. The survey data were obtained from a food factory (coffee shop) in Semarang. Population sampling is used. Data are collected through research methods such as direct surveys. Structural Equation Modeling (SEM) testing is used for data analysis. The model of the mathematical equation is used in a statistical test to show the effects of the independent variables on the dependent and controlled variables. The results of the study suggest that: 1) Purchasing decisions do not directly affect lifestyle. 2) The decision to buy has a negative effect on the price. 3) During the COVID-19 epidemic, lifestyle had a positive effect on purchasing decisions. 4) Transmission variable COVID-19 had a positive effect on purchasing decisions during the epidemic. Before the plague, prices were lower than usual, but coffee experts kept their distance, avoided crowds, and cared about their health.
\end{abstract}

Key-Words: Lifestyle, price, purchasing decision and Covid-19 Pandemic

Received: June 12, 2021. Revised: December 10, 2021. Accepted: January 7, 2022. Published: January 10, 2022.

\section{Introduction}

At present, Indonesia's trade is developing very fast, especially in the food sector. According to Andanawar, many factors influence the development of food production, such as demographics, economic status, and lifestyle [1]. This can be seen in many food companies with different concepts, such as family restaurants, street stalls, taverns, and cafes. Food production is considered to be promising, so food is a basic human need. The growing demand and passion of consumers in the food industry is intensifying the level of competition in the business world [2]. This fact requires entrepreneurs to come up with new ideas to win the competition. Commercial competition between similar companies has intensified, with traders actively involved in attracting customers. This is in line with the company's marketing philosophy that it must create, deliver, and deliver customer value more effectively than its competitors in its chosen target market [3]. Customers' purchasing decisions are influenced by the company's ability to attract customers.

The purchasing decision is a complex process that aims to evaluate two or more different behaviors and choose one [4]. Even if consumers value the brand, there are two general factors that influence buyers' desires and purchasing decisions. The first is the attitude of others. How much one person's attitude reduces our other choices depends on two things: 1) the strength of the other person's negative attitude toward our choices, and 2) our motivation to follow the desires of others. The stronger the negative attitude of another person, the closer we are to that person, the more likely we are to change the purpose of our purchase. The second factor is a situational factor that can change the purpose of the purchase [5]. Consumers' purchasing decisions are a psychological trend of choice. In other words, you have to be able to make other choices when making decisions.

A lifestyle is a person's way of life on this earth and is expressed in his actions, interests and views. Lifestyle describes the person as a whole interacting with the environment [5]. Lifestyle can greatly influence a person's decision about where to spend their time and money (for example, choosing a cafe or shop). Lifestyle is closely related to current lifestyle. A well-managed lifestyle allows you to identify and monitor changes in customers' lives during the marketing process so that marketing can achieve the right goals. Studies by Rizki Arianto (2018), Agung Sapta Vijaya (2017), Brian Givani, and Slamet Harry Vinarno (2019) have found that lifestyle influences purchasing decisions [2], [7], [8]. However, a study by Mohammad Arif( 2018) showed that lifestyle did not affect purchasing decisions [9].

Another aspect that influences purchase decision is price. It is very common when customers are looking for an economical and high quality product, and this fact increases the price significantly. Price is mainly related to product costs, but in fact the industry must estimate the cost, ability, quality and price of a product that 
competes in the market. Cheap dedication that is tried by the client to get a price, product or service [10]. In addition, price is a significant factor for customers to decide whether to do business or not [11].

The low price of the product usually increases marketing. At the same time, increasing the price of a prestigious product will increase marketing, because high-priced products reflect people's income. Research by Widha Emil Luthfia (2012), Dhien Alfath Aulya (2013) and Rafika Saski Fitriani (2013) prove that price has an important influence on purchasing decisions [12]-[14]. But research by Rahisto Awan Saputro(2015) proves that price does not affect to purchase decisions [15].

To improve the description of the impact of the Covid-19 epidemic on industrial purchasing decisions, the results of this research are expected to provide a balanced elastic participation that influences the results of price bond research. Logistics provisions. Considering the lifestyle of customers and product price markers, the available research is expected to urge entrepreneurs to find more customers. This research intends to strengthen the research conducted by Chaterina, I (2019) entitled "Effect of Lifestyle and Prices on Purchase Decision of E'Chick Consumers". There is a comparison of the results in terms of prices, as a result, researchers think that the Covid-19 endemic is an elastic moderation [16].

\subsection{Problem Formulation}

Based on the background of problems that have existed since the beginning, this research appears to find out small buying decisions. This research also aims to identify the factors that influence purchasing decisions that are less than optimal, such as lifestyle and prices moderated by the COVID-19 epidemic.

\section{Literature Review}

Based on the background that has been described above, to the conclusion that this research problem is a purchase decision that is less than optimal. Factors that influence purchasing decisions that are less than optimal include lifestyle and prices, which are moderated by the Covid-19 endemic atmosphere.

\subsection{Purchasing Decision}

For Peter and Olson (2009) purchase decision is a structured method that intends to assess 2 or more attitude substitutes and choose one of them, meaning that there must be alternative options when making a purchase decision [4].

The decision-making perspective emphasizes more on a rational information processing approach to consumer buying behavior [17]. Decision-making by consumers to buy a product begins with an awareness of the needs and desires called need arousal [18]. If they are aware of their wants and needs, consumers will seek more information about products and make purchasing decisions. Marketers must understand the behavior of buyers to make purchases that are influenced by certain buyer characteristics and personal decision-making processes.

The way intellectual bottom-up plays a significant role in controlling how customers actually make their buying decisions. For Kotler (2007), the purchase decision process includes 5 steps [5]:

\section{Problem recognition}

When the consumer masters the problem or request caused by internal or external stimuli, the buying process begins. If the demand is recognized and recognized, the customer will choose some requests that need to be addressed immediately or some problems that can be postponed, and of course there are requests that need to be addressed immediately. Therefore, the logistics method begins at this step.

2. Information Search

A customer who has identified his needs will seek the most data to fulfill them.

3. Evaluation of Alternatives

After searching for the most data, the customer will use that data to evaluate several brand substitutes in one option.

4. Purchase Decision

In making a purchase intention, customers can make 5 sub-decisions: brand, dealer, quantity, duration, and payment procedures.

5. Post Purchase Behavior

After a purchase, customers may face disharmony discrepancies for noticing special features that are annoying or following exciting situations about other brands, and will always be wary of data to support their decisions. Sales communications must share beliefs and judgments that confirm the customer's choice and help him feel secure with the brand. The marketer profession does not end just when the product is purchased. Marketers must monitor post-purchase happiness, post-purchase action, and post-purchase product usage.

The perspective of collecting determinations emphasizes a logical data processing approach to customer buying attitudes [17]. The collection of decisions to make purchases made by customers because there is an understanding of wants and desires is called need arousal [18]. If they are aware of their wants and needs, customers will seek more information about the desired product. The data search method will focus customers to create various data about the desired product. After the availability of some data, the customer 
will evaluate the data by making a replacement purchase. The next day, customers will choose the option to buy using various criteria.

\subsection{Lifestyle}

Lifestyle is referred to as a person's way of life, including how a person uses his money, how he spends his time and the like. Hawkins and Coney (2005) reported that a person's lifestyle will affect desires, life attitudes, and buying attitudes. [19]. This will ultimately determine the purchase decision of customers who will return to a lifestyle that will affect their consumption patterns.

According to Kotler in Susanto (2013: 1), people's lifestyles in the world are expressed in certain activities, interests, and opinions, in the sense that in general a person's lifestyle can be seen from the routine activities he does, what he thinks. about everything around him and how much he cares about it and also what he thinks about himself and the outside world [20].

Student lifestyles can change, but this change is usually due to changing needs. During puberty period, parents are no longer become the models, otherwise, the people in the same age will become the main models [21]. This subject focuses students to imitate the attitudes of many people around them. This imitation pattern is especially felt by young people. Young people often make friends with their peers. In special gatherings, young people take turns giving about many things, including lifestyle. Students in the late youth era are generally tempted to use what the majority of their peers use. Contemporary groups are recognized to influence young people's evaluations and decisions regarding their behavior [22]. Conger (1991) and Papalia and Olds(2001) suggest that peer groups are an important reference point for young people in terms of lifestyle-related thoughts and actions [23], [24]. Client psychographics is often called lifestyle analysis because it is seen from two forms, namely self-design and lifestyle. Psychographic research is always based on AIO (Activity, Interest and Opinion) [25]. The market share of young children is a prime target for producers. Students are late youths with a great propensity to consume. Often, students consume an object or service not just because they need it. However, the level of consumption perception that often occurs in students when consuming is a symptom of consumptive behavior.

Arnold Mitchell of SRI International (Kotler, 2005) adds 9 lifestyles based on the idea that people have several steps of progress. [5]. The nine lifestyles are:

1. Survivors, are people who are less Asian and tend to face hopelessness, deprivation, alienation such as elderly people, people whose health levels are small and their educational levels are small.

2. Sustainers, are underprivileged residents who are still struggling to get away from poverty.

3. Belongers, namely conventional and conservative are a lot of conventional and conventional people who miss the past, do not dare to try new things and prefer to get used to it than emerge.

4. Emulators (People who Like to Exceed), are people who like to dream, try to leave their status and want to be popular.

5. Achievers, are the nation's superiors who create, practice the system and enjoy a good life.

6. "I am Me" (People Who Like to Focus on Himself), is a young child who only considers himself and likes to ponder.

7. Experientialists (People who Like to Try Something New), are people who like to pursue the riches of the heart and want to experience firsthand what life has to offer.

8. Societally Conscious (People who have a high awareness of social problems), are people who have a great sense of responsibility and want to correct the situation in society.

9. Integrateds (Established Personality), is a person who has fully reached intellectual maturity and can mix the factors of the heart and the factors of the environment.

\subsection{Price}

Price is the amount of money (plus some products if possible) required to compile a mix of products and services [26]. Meanwhile, Kotler and Armstrong (2008) describe the price in a small way as the amount of money that is weighted for a product or service [27]. It is broadly defined as the amount of money weighted for a product or service, or the amount of money a customer exchanges for the benefit of having or using a product or service. From the meaning above, it can be concluded that to have or use a product or service, the customer must use some money as a change tool.

According to Tjiptono (2002) It is broadly defined as the amount of money that is weighed against a product or service, or the amount of money that a client exchanges for the benefit of having or using the product or service [28]. From the interpretation above, it can be concluded that to have or use a product or service, the client must use some money as a change tool.

Next for Dertwinkel pricing can be tried based on the following objectives [29]:

1. By modifying behavior

People talk based on several alibis, including: seeking happiness, seeking encouragement, sharing encouragement or instructions, sharing 
data, expressing inspiration and opinions, and strengthening attitudes.

2. By telling

Prices can be used to inform the market of industry deals. Data on prices are usually more appropriate to be informed at an early stage of the product life cycle. Price helps customers in quoting purchase decisions.

3. By persuading

Persuasive prices are less popular with residents. On the other hand, prices arrive with the disposition of persuasion. The price is used to urge purchases. A persuasive price will reign when the related product begins to penetrate the developmental steps in the product life cycle.

4. By reminding

Setting prices is trying to keep the product brand in the minds of people, especially at the maturity stage in the product life cycle. This means that the industry can at least take care of the existing consumers.

\subsection{Covid-19 Pandemic}

COVID-19 is one of the most serious challenges faced by the authorities and the world in this era[30]. COVID-19 brings a lot of violent intellectual, social and professional changes, such as running out of work, small funds, worries and mental stress during overseas visits, physical and psychological health problems in an uncertain future [31]. As a result, it forced some countries to practice lockdown policies to avoid the spread of the corona virus. In Indonesia, the Social Segregation of Great Value (PSBB) policy was applied to suppress the spread of this virus. The government of West Java Province measured the level of efficient reproduction (Rt) using the SimcovID model (Imitation and Modeling of Covid-19 Indonesia). SimcovID is a combined team consisting of researchers from various universities, such as ITB, Padjajaran University, YGM, UGM, ITS, UB, and Undana, and researchers from foreign universities, namely Essex\&amp; Khalifa University, University of Southern Denmark, and Oxford University. Based on the Kalman Penapis method, which stands for the Bayesian Sequential method, there are 3 markers in measuring the Covid-19 breeding indicator (Rt), namely the number of active positive problems, the number of recoveries, and the number of deaths. sourced from the duration of each day.

Due to the Covid-19 endemic, West Java divides nature or areas into several markers according to color, as follows: Level 5 (dark realms) critical (numbers 8-11) - 10\% economy, Level 4 (red realms) very large ( number 12-14)$30 \%$ economy, Level 3(yellow realm) acute(number 15-17)- 60\% economy, Level 2(blue realm) again(number 21- 24)- 90\% economy, Level 1(natural green) small( numbers 21- 24)- 100\% economy. This expansion was followed by many other regions providing separation to assist regions in experiencing the Covid-19 endemic. In this way, color becomes a sign of the significance of the Covid-19 endemic in an area, including the Semarang City area which is the research position.

The impact of the COVID-19 endemic, the mandate of social distancing and lockdown has greatly disturbed the buying and shopping routines of customers with their consumption patterns [32]. The latest methods of distributing or experiencing concerns and risks experienced, demographic changes and technological developments have also led to the emergence of new routines among customers. Slickdeals surveyed nearly 2,000 Americans on a popular online shopping program that is booming and found that customers reported making more impulse purchases during the COVID-19 pandemic than before the epidemic [33]. For example, in January 2020, the average American spending on impulse purchases was about $\$ 155.03$ per month prior to the COVID-19 outbreak, while in April 2020 the average American spending on impulse purchases was $\$ 182.98$, with an $18 \%$ increase [33]. For example, in January 2020, the average American spending on impulse buying was near $\$ 155.03$ per month prior to the COVID-19 outbreak, whereas in April 2020 the average American spending on impulse buying was $\$ 182.98$, an $18 \%$ increase[33] . Since the early days of this endemic, it is reported that close to $46 \%$ of customers ordered groceries online for the first time. Close to $71 \%$ of customers ( 3 out of 4 ) say they plan to make and buy online at an increasing rate due to concerns and uncertainty about the COVID-19 outbreak [34].

\subsection{Research Model}

COVID-19 is one of the most difficult challenges faced by the authorities and the business sector in this era [35].

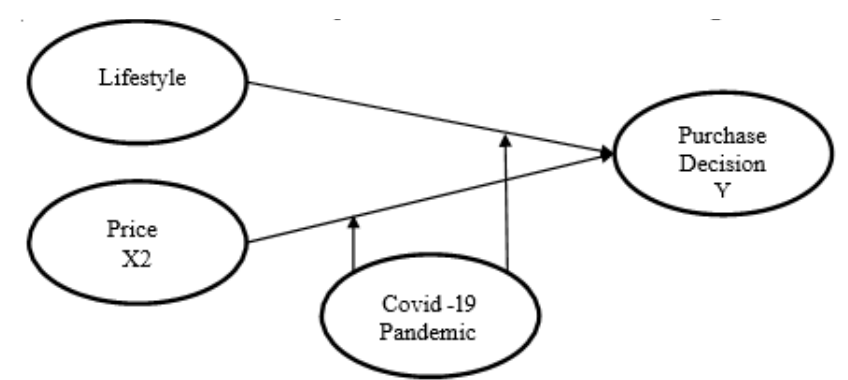

Fig. 1: Research Model

\section{Research Method}

This research is a quantitative research whose type of information is in the form of numbers. For measuring elastic ratios in this study, researchers used unobserved 
measurements because all the elastics involved in making free elastics, intermediate elastics and bound elastics are potential elastics. To examine unobserved variables, researchers used the Structural Equation Modeling (SEM) analytic experimental apparatus. The participating population is the customer of Kopi 57 Coffee Shop in Semarang. The method of collecting illustrations uses a purposive sampling procedure with a benchmark of customers who have purchased products at Coffee Shop Kopi 57 Semarang at least 5 times.

The base of information in this research is basic information and inferior information. The main information in this case is Coffee Shop Kopi 57 customers in Semarang who meet the requirements and inferior information is obtained from posts, daily, and previous research results. The information collection method used is a questionnaire with a Likert ratio and library research such as novels, magazines, newspapers, and posts. The information analysis procedure in this research is a cause-andeffect form to try out the assumptions put forward, using SEM (Structural Equation Models).

\section{Result and Discussion}

\subsection{Evaluation of Residual Value}

After analyzing the level of unidimensionality of the potential elastic maker markers tested with confirmatory aspect analysis, the next analysis is a full form Structural Equation Form (SEM) analysis. Analysis of the results of processing information in the full form of SEM is tried by carrying out suitability experiments and statistical experiments. The results of processing information for a complete form of SEM analysis are shown in the following:

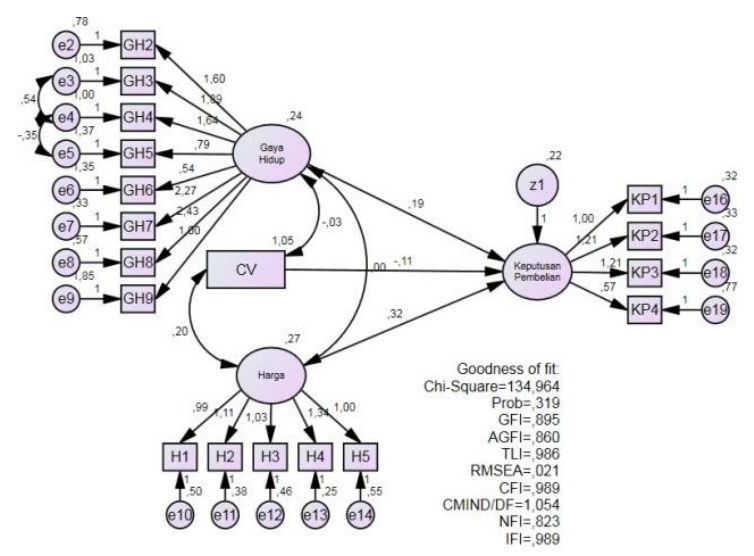

Fig. 2: The full model SEM analysis

The probability value obtained was is $0.319>0.05$ which indicated that the model was fit. The output of the full Model SEM in this study is presented as follows:
Table 1. Full Model Output

\begin{tabular}{|c|c|c|c|}
\hline $\begin{array}{l}\text { Goodness of fit } \\
\text { index }\end{array}$ & 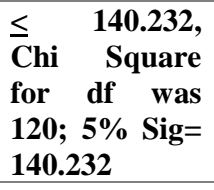 & Estimate & Information \\
\hline Chi-square $\left(\chi^{2}\right)$ & $\leq 140.232$ & 134.964 & Good \\
\hline $\begin{array}{l}\text { Significance } \\
\text { probability }\end{array}$ & $\geq 0.05$ & 0.319 & Good \\
\hline RMSEA & $\leq 0.08$ & 0.021 & Good \\
\hline GFI & $\geq 0.90$ & 0.895 & Marginal \\
\hline AGFI & $\geq 0.90$ & 0.860 & Marginal \\
\hline CMIN/DF & $\leq 2.00$ & 1.054 & Good \\
\hline TLI & $\geq 0.95$ & 0.966 & Good \\
\hline CFI & $\geq 0.95$ & 0.989 & Good \\
\hline
\end{tabular}

It was shown that the existing tes met the specified requirements or close to the recommended value. In this case GFI and AGFI values were $0.8<0.90$ so that they were in the marginal category. Thus, it can be stated that the model was declared fit for analysis [36].

\subsection{Hypothesis Test}

The full model used after the test was as follows:

Table 2. Regression Weights: (Group number 1 Default model)

\begin{tabular}{llllllc}
\hline Estimate & & \multicolumn{3}{c}{ S.E. C.R. } & P & Label \\
\hline Purchasing_Decisio & $<--$ Lifestyl & .190 & .12 & 1.519 & .12 & par_1 \\
$\mathrm{n}$ & $-\mathrm{e}$ & 5 & & 9 & 2 \\
Purchasing_Decisio & $<--$ Price & .316 & .13 & 2.410 & .01 & par_1 \\
$\mathrm{n}$ & - & & 1 & & 6 & 5 \\
Purchasing_Decisio & $<--$ CV & - & $.056-$ & .03 & par_1 \\
$\mathrm{n}$ & - & .115 & 2.064 & 9 & 8 \\
\hline
\end{tabular}

Based on the output results above, the results of hypothesis test were as follows:

H1: Lifestyle had no positive effect on Purchase Decision at Kopi 57 Coffee Shop in Semarang. Based on the data from data processing, it can be seen that the $\mathrm{P}$ value (probability) was $0.129>$ 0.05 . This value indicated a result that did not meet the requirement for $\mathrm{P}(0.05)$, so that $\mathrm{H} 1$ in this study was not accepted.

H2: Price had a positive effect on Purchase Decision at Kopi 57 Coffee Shop in Semarang. Based on the data from data processing, it can be seen that the $\mathrm{P}$ value (probability) was $0.016<0.05$. This value indicated a result that met the requirements for $\mathrm{P}$ (0.05), then $\mathrm{H} 2$ in this study was accepted.

H3: The Covid-19 pandemic had a negative effect on Purchase Decision at Kopi 57 Coffee Shop in Semarang. Based on the data from data processing, it can be seen that the $\mathrm{P}$ value (probability) was $0.039<0.05$. This value indicated a result that mets the requirement for $\mathrm{P}(0.05)$, then $\mathrm{H} 3$ in this study 
was accepted

H4: The Covid 19 pandemic moderates the relationship between Lifestyle and Purchase Decisions at the AN Kopi Coffee Shop in Wonosobo. Based on the processed data, it can be seen that the parameter coefficient value is 12,142 with a probability of 1,000 or significant at 0.10 . So it can be concluded that the Covid 19 pandemic variable is a moderating variable or a variable that moderates the relationship between Lifestyle and Purchase Decisions and the hypothesis is accepted.

H5: The Covid 19 pandemic moderates the relationship between price and Purchase Decisions at the AN Kopi Coffee Shop in Wonosobo. Based on the processed data, it can be seen that the parameter coefficient value is 12.656 with a probability of 1 or significant at 0.10 . So it can be concluded that the Covid 19 pandemic variable is a moderating variable or a variable that moderates the relationship between Price and Purchase Decisions and the hypothesis is accepted.

\subsection{Coefficient of Determination Test}

The coefficient of determination essentially measures the model's ability to explain the independent variation to the dependent variable [37].

Table 3. Squared Multiple Correlations: (Group number 1 - Default model)

\section{Estimate}

\section{Purchasing_Decision}

.146

Based on the table above, the effect size of the coefficient of determination (R2) was 0.146 or $14.6 \%$. Therefore, it can be explained that $14.6 \%$ of Purchase Decision were influenced by Lifestyle and Price factor while $85.4 \%$ are influenced by other variables.

\section{Discussion}

\subsection{Effect of Lifestyle on Purchase Decision}

Based on the results of the analysis above, it was shown that estimates for lifestyle on Purchase Decision had a CR value of 1.519 and a probability of 0.129 . The two values obtained did not meet the requirements for $\mathrm{H} 1$ acceptance, namely the $\mathrm{CR}$ value of $1.519<1.96$ and the probability of $>0.05$. Thus it can be concluded that lifestyle had no positive effect on purchasing decision among consumers of Kopi 57 Coffee Shop in Indonesia Semarang. This meant that coffee connoisseurs did not highlight their lifestyle in their decision to buy coffee at Coffeshop Kopi 57 in Semarang.

\subsection{Effect of Price on Purchase Decision}

Based on the results of the analysis above, it was shown that the estimates for price on purchase decision had a CR value of 2.410 and a probability of 0.016 . The two values obtained met the requirements for $\mathrm{H} 2$ acceptance, namely the $\mathrm{CR}$ value of $2.410>1.96$ and the probability of $0.016<0.05$. Thus, it can be concluded that the price had a positive effect on Purchase Decision among consumers of Kopi 57 Coffee Shop in Semarang. This meant that the cheaper the price, the faster the consumer would make a decision to buy and vice versa.

\subsection{Effect of the Covid-19 Pandemic on Purchase Decision}

Based on the results of the analysis above, it was shown that estimates for the Covid-19 pandemic on Purchase Decision had a CR value of -2.064 and a probability of 0.039 . The two values obtained met the requirements for $\mathrm{H} 3$ acceptance, namely the CR value of $-2.064>1.96$ and a probability of $0.039<0.05$. Thus, it can be concluded that the Covid-19 pandemic had a negative effect on purchasing decision among consumers of Kopi 57 Coffee Shop in Semarang. This meant that if the Covid-19 pandemic spreaded, consumers would delay making decision to buy and vice versa.

\subsection{The Covid-19 Pandemic Moderated the Effect of Lifestyle on Purchase Decision}

Based on results of the analysis above, it was shown the estimation that the Covid-19 pandemic moderated the relationship between lifestyle and Purchasing Decision at Kopi 57 Coffee Shop in Semarang with a parameter coefficient value of 12.142 and a probability of 1.000 or significant at 0.10 . Thus, it can be concluded that the COVID-19 pandemic variable was a moderating variable or a variable that moderated the relationship between Lifestyle and Purchase Decision.

\subsection{The Covid-19 Pandemic Moderated the Effect of Price on Purchase Decision}

Based on results of the analysis above, it was shown the estimation that the Covid-19 pandemic moderated the relationship between price and Purchasing Decision at Kopi 57 Coffee Shop in Semarang with a parameter coefficient value of 12.656 and a probability of 1.000 or significant at 0.10 . Thus, it can be concluded that the COVID-19 pandemic variable was a moderating variable or a variable that moderated the relationship between Price and Purchase Decision. 


\section{Conclusion}

Based on the results of the research that has been done, some conclusions can be drawn as follows:

1. There was no direct effect of Lifestyle on Purchase Decision. This is not in line with the studies conducted by D Nata Wijaya, et al in 2018, Bryan Givan and Slamet Heri Winarno in 2019 and Ivana Chaterina in 2016.

2. There was a negative effect of price on Purchase Decision. This finding is in line with a study conducted by Nova Dhita Kurniasari in 2013, Rosvita Dua Lembang in 2010 and Anindya Rachma Andanawari in 2014.

3. There was a positive effect of Lifestyle on Purchase Decision with the COVID-19 Pandemic as a moderating variable. It turned out that the Covid-19 pandemic changed the lifestyle of consumers of Kopi 57 coffee shop in Semarang. Coffee connoisseurs were actually more concerned about their health by keeping their distance and avoiding crowds rather than highlighting their lifestyle by enjoying coffee.

4. There was a positive effect of Price on Purchase Decision with the COVID-19 Pandemic as a moderating variable. It turned out that the Covid-19 pandemic changed the lifestyle of consumers of Kopi 57 coffee shop in Semarang. Coffee connoisseurs were actually more concerned about their health by keeping their distance and avoiding crowds even though prices were set cheaper than usual before the pandemic.

Based on this research, it is expected that in the future:

1. Consumers of Kopi 57 Coffee Shop in Semarang must further improve their Lifestyle on Purchase Decision in order to produce maximum performance by increasing the Lifestyle they own.

2. Employees of Kopi 57 Coffee Shop in Semarang must improve Islamic business ethics to support their performance so that it is in accordance with sharia guidelines that become the base for their operations.

\section{References:}

[1] A. R. Andanawari, "Pengaruh Harga, Lokasi dan Kualitas Produk Terhadap Keputusan Pembelian (Case Study at Stove Syndicate Cafe Semarang).," 2014.

[2] R. Arianto, "Pengaruh Gaya Hidup dan Harga Terhadap Keputusan Pembelian di Coffe Shop Cekopi Solo Menggunakan Variabel Intervening Sikap Konsumen," 2018.

[3] P. Kotler, "Manajemen pemasaran perspektif asia," Fandy Tjiptono (Penerjemah), Penerbit
Andi Yogyakarta, 2012.

[4] P. J. Peter and J. C. Olson, Perilaku Konsumen dan Strategi Pemasaran. 2013.

[5] P. Kotler and K. L. Keller, Manajemen pemasaran Jilid 1. 2009.

[6] S. Lysonski and S. Durvasula, "Consumer decision making styles in retailing: Evolution of mindsets and psychological impacts," $J$. Consum. Mark., 2013, doi: 10.1108/07363761311290858.

[7] A. S. Wijaya, "Pengaruh Gaya Hidup, Kualitas Pelayanan dan Store Atmosphere Terhadap Keputusan Pembelian dan Dampaknya Terhadap Pembelian Ulang (Case Study among Consumers of SAHABAT KOPI Ciputat).," 2017.

[8] A. C. J. Emor, A. L. Lonto, and T. Pangalila, "PENGARUH TINGKAT PENDIDIKAN ORANG TUA TERHADAP PENDIDIKAN ANAK DI KELURAHAN PINASUNGKULAN KECAMATAN RANOWULU KOTA BITUNG," J. Civ. Educ. Media Kaji. Pancasila dan Kewarganegaraan, 2019, doi: 10.36412/ce.v3i1.907.

[9] M. Arif, "Pengaruh Store Atmosphere, Lokasi dan Gaya Hidup Terhadap Keputusan Pembelian Soban Cafe Medan," 2018.

[10] A. Monroe, A. C., \& Van Riel, "Marketing Antecedent of Industrial Brand Equity: An Empirical Investigation in Specialty Chemical," Ind. Mark. Manag., vol. 12, no. 1, pp. 841-847, 2005.

[11] H. W. Kim, Y. Xu, and S. Gupta, "Which is more important in Internet shopping, perceived price or trust?," Electron. Commer. Res. Appl., 2012, doi: 10.1016/j.elerap.2011.06.003.

[12] W. E. Luthfia, "Analisis Pengaruh Kualitas Produk, Harga dan Kualitas Layanan Terhadap Keputusan Pembelian pada Coffe Shop Kofisyop Tembalang," 2012.

[13] D. A. Aulya, "Analisis Pengaruh Produk, Harga dan Kualitas Pelayanan Terhadap Keputusan Pembelian (Study at Stove Syndicate Coffe Shop Semarang)," 2013.

[14] R. S. Firiani, "Analisis Pengaruh Harga, Persepsi Kualitas, Kesadaran Merek dan Asosiasi Merek Terhadap Keputusan Pembelian Teh Botol Sosro (Case Study among Bachelor students of Diponegoro University)," 2015.

[15] R. M. Saputro, "Analisis Pengaruh Kualitas Produk, Harga, Kualitas Pelayanan dan Lokasi Terhadap Keputusan Pembelian (Case Study at Grand Panorama Resto Semarang)," 2015.

[16] I. Chaterina, "Pengaruh Gaya Hidup dan Harga 
Terhadap Keputusan pembelian konsumen e'chick," J. Manaj. dan StartUp Bisnis, 2016.

[17] M. Mowen, J. C., \& Minor, Perilaku konsumen. Jakarta: Erlangga, 2002.

[18] Sutisna, "Perilaku Konsumen: Teori dan penerapannya dalam Pemasaran," Ghalia Indones. Jakarta, 2003, doi: 10.1007/BF01013984.

[19] et al. Hawkins, Consumer Behavior: Building Marketing Strategy. Boston: Mc Graw, 2005.

[20] Susanto, Pembenihan Ikan Mas. Yogyakarta: Kanisius, 2004.

[21] K. Fudyartanta, Psikologi perkembangan. Yogyakarta: Pustaka Pelajar, 2012.

[22] D. Albert, J. Chein, and L. Steinberg, "The Teenage Brain: Peer Influences on Adolescent Decision Making," Current Directions in Psychological Science. 2013, doi: 10.1177/0963721412471347.

[23] J. A. Conger, "Inspiring others: the language of leadership.," Executive, 2011, doi: 10.5465/ame.1991.4274713.

[24] R. D. E. Papalia, S. W. Olds, and R. D. Feldman, "Physical and Cognitive Development in Adolescence," in Human Development, 2008.

[25] E. N. Torres, "The Influence of Others on the Vacation Experience: An Ethnographic Study of Psychographics, Decision Making, and Group Dynamics Among Young Travelers," J. Hosp. Mark. Manag., 2015, doi: 10.1080/19368623.2015.960991.

[26] B. Swastha, Manajemen Pemasaran Modern. 2008.

[27] P. Kotler and G. Armstrong, Principles of Marketing 17th Global Edition. 2018.

[28] F. Tjiptono, Pemasaran Jasa. Malang: Bayumedia Publishing, 2005.

[29] M. Dertwinkel-Kalt and C. Wey, "MultiProduct Pricing and Minimum Resale Price Maintenance," SSRN Electron. J., 2021, doi: 10.2139/ssrn.3764435.

[30] E. P. Bayham, J., \& Fenichel, "Impact of school closures for COVID-19 on the US health-care workforce and net mortality: a modelling study," Lancet Public Heal., vol. 5(5), pp. e271-e278., 2020.

[31] J. Palepu, K. G., Healy, P. M., Wright, S., Bradbury, M., \& Coulton, "Business analysis and valuation: Using financial statements," Bus. Anal. Valuat. Using Financ. statements., no. Cengage AU.,
2020.

[32] N. Donthu and A. Gustafsson, "Effects of COVID-19 on business and research," Journal of Business Research. 2020, doi: 10.1016/j.jbusres.2020.06.008.

[33] Slickdeals, "No Title," https://slickdeals.net/, 2020. .

[34] R. customer Experience, "Retail customer experience,"

https://www.retailcustomerexperience.com/, 2020 . .

[35] P. Cankurtaran and M. B. Beverland, "Using design thinking to respond to crises: B2B lessons from the 2020 COVID-19 pandemic," Ind. Mark. Manag., 2020, doi: 10.1016/j.indmarman.2020.05.030.

[36] I. Ghozali, "Model Persamaan Struktural, Konsep dan Aplikasi Dengan Program AMOS 24 Update Bayesian SEM," in Badan Penerbit Universitas Diponegoro ISBN: 979-704-233-2, 2017.

[37] I. Ghozali, "Aplikasi Analisis Multivariate Dengan Program IBM dan SPSS.," in aplikasi analisis multivariate dengan program ibm spss 19, 2013.

\section{Contribution of individual authors to the creation of a scientific article}

Andika Baskara conceived of the presented idea, developed the theory and verified the analytical methods.

Andika Baskara encouraged Sukamto to collect the data and supervised the findings of this work. All authors discussed the results and contributed to the final manuscript.

\section{Creative Commons Attribution License 4.0 (Attribution 4.0 International, CC BY 4.0)}

This article is published under the terms of the Creative Commons Attribution License 4.0

https://creativecommons.org/licenses/by/4.0/deed.en_US 